\title{
Competence and competence frameworks in career guidance: complex and contested concepts
}

\author{
Ronald G. Sultana
}

Received: 12 April 2008/Accepted: 21 August 2008/Published online: 30 October 2008

(C) Springer Science+Business Media B.V. 2008

\begin{abstract}
This paper considers some of the debates surrounding the term competence and the relevance that these have for the development of competence frameworks. Such frameworks are increasingly on the agenda, since they purport to support training programme development, to identify competence gaps, to promote self-development, and to ensure common standards. This paper shows, however, that notions of competence have specific meanings in particular contexts, that they have been contested, and that they have fallen into and out of favour over time. The paper concludes by teasing out the implications that competing definitions of competence have for the guidance field.
\end{abstract}

Résumé. Compétences et cadres de référence des compétences dans les conseils d'orientation: concepts complexes et contestés. Cet article considère certaines des discussions entourant le terme "compétence" et leur pertinence pour le développement d'un cadre de référence pour ce concept. De tels cadres sont de plus en plus à l'ordre du jour, puisqu'ils prétendent soutenir le développement de programmes de formation, identifier les lacunes dans les compétences, favoriser le développement de soi et constituer des normes communes. Cet article montre cependant que les notions recouvertes par le terme de compétence ont des sens spécifiques dans des contextes particuliers, qu'elles ont été contestées et qu'elles ont du succès ou tombent en désuétude avec le temps. L'article conclut en démêlant les implications que les définitions concurrentes de la compétence ont pour le champ du conseil.

Zusammenfassung. Kompetenz und Kompetenzmodelle in der beruflichen Beratung: Komplexe und konkurrierende Ansätze. Dieser Artikel betrachtet einige der Diskussionen rund um den Begriff "Kompetenz" und die Bedeutung

R. G. Sultana $(\bowtie)$

Euro-Mediterranean Centre for Educational Research, University of Malta,

Msida, MSD 2080, Malta

e-mail: ronald.sultana@um.edu.mt 
dieser Diskussionen für die Entwicklung von Kompetenzmodellen. Solche Modelle sind zunehmend von Interesse, weil sie von sich selbst behaupten, sie seien eine wirksame Unterstützung von Ausbildungsprogrammen, könnten Kompetenzdefizite identifizieren, seien förderlich bei der persönlichen Weiterentwicklung, und sie würden allgemeine Standards sicherstellen. Dieser Artikel zeigt jedoch auf, dass die Auffassungen über Kompetenz in unterschiedlichen Kontexten durchaus unterschiedliche Bedeutungen haben, dass zwischen diesen Auffassungen Konkurrenzwettbewerbe stattgefunden haben, und dass die einzelnen Ansätze im Lauf der Zeit mehr oder weniger in Mode kamen oder in den Hintergrund traten. Abschließend filtert der Artikel die Bedeutungen heraus, die sich aus konkurrierenden Definitionen von Kompetenz für den Beratungsbereich ergeben.

\section{Resumen. Competencia y marcos de competencia en la orientación para la} carrera: conceptos complejos y cuestionados. En este artículo se presentan algunos de los debates en torno al término "competencia" y su relevancia para el desarrollo de marcos de competencia. Dichos marcos están cada vez más en auge, puesto que pretenden favorecer el desarrollo de programas de formación, identificar lagunas en las competencias, promover el auto-desarrollo, y garantizar estándares comunes de formación. En este artículo se demuestra, sin embargo, que los conceptos de competencia tienen significados específicos en contextos particulares, que se han discutido y cuestionado, y que se ha estado tanto a favor como en contra de ellos a lo largo del tiempo. El artículo concluye extrayendo las implicaciones que tienen las distintas definiciones de competencia para el campo de la orientación.

\section{Keywords Competence $\cdot$ Competence frameworks $\cdot$ Training}

There is a renewed interest internationally in identifying the competences that are required by career guidance (CG) practitioners. This, it is thought, facilitates the generation of competence frameworks which help demystify the profile of a profession by making the required knowledge and skills base more transparent, and by providing a vocabulary through which expectations and processes can be made evident and public. Such frameworks can consequently serve as a guide to develop training programmes, to identify competence gaps in both individuals and in organisations providing guidance services, to promote self-development in targeted ways, and to ensure common reference standards.

The International Association for Educational and Vocational Guidance (IAEVG), for instance, launched a research project in 1999 with a view to identifying and agreeing upon the kind of competences practitioners needed to perform their jobs effectively. The project built on previous initiatives, such as the Canadian Standards and Guidelines for Career Development practitioners (cf. National Steering Committee for Career Development Standards and Guidelines, 2001), and consulted practitioners and trainers in 41 countries, with its final report to the Association's General Assembly identifying eleven "core competencies" and ten areas of "specialised competencies" (International Association for Educational and Vocational Guidance, 2004; Repetto, 2008). In Australia, the Career Industry 
Council published a set of professional standards for career development practitioners (Career Industry Council of Australia [CICA], 2006). These standards have now been adopted by the Council and its member organisations and will be required from all practitioners as from 2012.

In the EU (European Union), a Leonardo da Vinci-funded project called EAS (the European Accreditation Scheme for CG practitioners) was launched in 2006, having as a goal the development of a competence-based framework for accrediting CG practitioners at the European level, and to establish a network of European awarding bodies (Evangelista, 2007; Reid, 2007). Furthermore, one of the EU's agencies-CEDEFOP (The European Centre for the Development of Vocational Training)_commissioned the UK-based National Institute for Career Education and Counselling (NICEC) to carry out a major study in 2007 in order to determine the qualifications routes and competences needed by CG counsellors in the 27 member states, as well as in the European Economic Area countries.

This paper, which builds on a concept note prepared for NICEC in the context of the latter project, and on the feedback that the Institute's research fellows provided, sets out to account for some of the reasons why the competence approach has become attractive in the CG field, and to analyse some of the promises and pitfalls in this approach. In order to do so, it will consider definitions of competence, and examine how such competing definitions have implications for the development of a competence approach in CG. The reflections in this paper are largely based on experiences in the guidance field in the EU, but are likely to find resonance with readers beyond Europe.

\section{The rise, fall, and rebirth of competence approaches}

The use of the notion competence as a master discourse supporting the identification of the skills needed in particular work profiles and professions has fallen in and out of favour over time. In the 1970s, for instance, the term competence gained prominence in the field of management and Human Resource Development (HRD), particularly in relation to the identification and selection of effective leaders for enterprises. High performing managers were observed, and a series of traits and skills which could be causally related to excellence were identified. These then became the building blocks for a reference framework that was used to select, assess and develop managers (see Delamare-Le Deist \& Winterton, 2005; Mulder, 2007). This approach influenced other fields, including various sectors in education, such as Vocational Education and Training (VET) and the initial and continued training of teachers. Competence frameworks became the basis for professional development programmes, with competence-based training (CBT) reaching a height of popularity in the late 1970s and early 1980s in the US, Australia, and across Europe.

By the mid-1980s and throughout the 1990s, a series of critiques challenged both the notion of competence itself, as well as competence-based approaches to education and training (see, for instance, Brown, Patrick, Tate \& Wright, 1994). Critiques focused not only on the fuzziness of the concept (Westera, 2001), but also on some of the key notions underpinning it, particularly those influenced by 
behaviourism. Some (e.g. Hyland, 1993, 1997; Norris, 1991) wondered, for instance, about the extent to which the notion of competence helped in understanding the relationship between propositional knowledge (knowing that), practical knowledge (knowing how), and procedural knowledge (knowing how to be), and that it indeed understated and belittled the role of knowledge and understanding, with the focus on skill serving to separate theoretical from practical knowledge and undermining values of personhood. Others found that, the concern with breaking down complex behaviours into more simple sub-skills in which novices could be trained stifled creative learning, glossed over individual differences between learners and, through the reduction of learning objectives to measurable outcomes and pre-specified ends, encouraged a mechanical "teaching to the test" approach (Barnett, 1994; Bates, 1995).

In sum, competence approaches were considered to focus on performance at the expense of complex intellectual processes, and reflection in and on action. In addition, competence frameworks based on this behaviouristic approach tended to be overly complex, bureaucratic and cumbersome to administer, and their usefulness was increasingly questioned as the inventory of competences/competencies became more finely differentiated. Such critiques served as a springboard catapulting competing approaches to learning and professional development to the fore. Amongst the most influential was the reflective practitioner model, which argued that it is not competences and behavioural training that determine how actors behave in a particular context, but rather their prior beliefs and personal theories (Schön, 1987). Many of the new approaches were underpinned by cognitive, and increasingly constructivist notions of learning, as opposed to behaviouristic ones (Coburn \& Stein, 2006).

\section{Resurgence of competence approaches in Europe}

Despite the major challenge to competence-based approaches, and the rise of more powerful learning and training models, it is interesting to note the revival of interest in the former just when it appeared that they had been definitively replaced by the latter. Indeed, competence-based approaches have once again become ubiquitous across Europe, particularly in the HRD and VET field, to the extent that we can again refer to a "competence movement" (Bates, 1995). This is having an impact on other, related fields, including career guidance.

There are several reasons that account for the renewed popularity of this approach in the EU. Delamare-Le Deist and Winterton (2005) note that, confronted by the fast pace of change, enterprises try to identify the new competences they require, placing pressure on education and training systems to respond to the changing skills profile needed. In this environment, a competence approach can have both economic and social usefulness, in that it facilitates the identification and validation of tacit competences acquired through experience, supporting attempts to quickly plug skill deficits while providing new opportunities for access to training and employment to those who failed to obtain formal certification through traditional routes. Furthermore, competence approaches promise to respond to concerns over quality assurance, facilitating greater accountability in terms of identifiable competence 
standards and levels of performance that can, in principle at least, be measured and tested. This also facilitates the differentiation of position and pay in a given organisation, or for roles across similar institutions (Roelofs \& Sanders, 2007).

The renewed popularity of competence-based approaches does not necessarily mean that the critiques levelled at it earlier have been resolved, or that the charge that several of its underlying premises may be faulty has been proved wrong. As Canning (2007) notes in his critique of the related concept of core skills, ideas, despite being deeply flawed, nevertheless survive and remain (or again become) popular because they perform powerful social functions in society. In this contribution, an attempt is made to delve more deeply into the complexities and contestations that mark the use of the notion of competence, identifying those aspects that the CG field would do well to consider.

\section{Defining "competence"}

The notion of competence has a long history. Mulder (2007) analyses Latin, English, French and Dutch roots of the term, and also looks at the way competence has been used since the 16th century in a variety of settings. He concludes that there is often a double meaning associated with the concept, in terms of both capability and authority: i.e. not just having the skill or ability to do something, but also having the permission to use it. This dual meaning is relevant, given that the current interest in the CG field is not just in identifying the sets of competences required by $\mathrm{CG}$ counsellors, but also in using evidence that practitioners or service providers possess these competences as a basis of qualification and accreditation routes. In other words, competence frameworks facilitate the development of mechanisms that recognise and accredit competence, leading to the authorisation of practise in the form of a publicly recognised warrant or a licence.

Time, however, has not been kind to the concept: much of the related literature bemoans the fact that the notion suffers from fuzziness and conceptual confusion. The confusion is even evident in relation to the spelling of the word, with indecisiveness as to whether one should use competence (plural: competences), or competency (plural: competencies). Many use these interchangeably, seeing no difference between them other than UK (former) and US (latter) spelling variants of the same word/concept. Others, particularly those writing in the HRD field (e.g. Chartered Institute of Personnel Development [CIPD], 2007) and in VET (e.g. Mulder, 2007), distinguish between the two by differentiating between behaviour and outcomes. Competency is thus defined as the behaviour that an employee (or an organization) must perform in a given situation in order to achieve high levels of performance (Woodruffe, 1991). Competence relates to an overall job done well, as measured against a system of minimum standards, and as demonstrated by performance and outputs. Such distinctions, which conceptualise the link between competence and competency as a whole-part relationship (Mulder, 2007), guard against confusing input competencies (a more atomistic concept labelling specific abilities) with output competences (a more integrative concept labelling performance). 
Attempts to get clarity by considering everyday usage of the term are not very helpful either. In English, the term competence tends to be used interchangeably with knowledge, skill, or ability. This semantic overlap is often also present in formal documents. Such slippage has had two consequences: it has contributed to the conceptual confusion referred to earlier, with some arguing that given its interchangeability with such terms as skills and ability, "competence is no more than an unclear label and does not increase our knowledge and understanding of the world" (Westera, 2001, p. 86). It has also led to what Clarke and Winch (2006, p. 256) call "conceptual inflation", where the attribution of multiple meanings to the term fosters ambiguity and problems with comprehension.

In recognition of the ambiguity of the concept, there have been several attempts to try to stabilize its meaning - a task made more difficult by the fact that the term is associated with different traditions in different countries, and underpinned by contrasting motivations for use in different fields, notably HRD and VET. Some of the more useful syntheses have been provided by Winterton and his colleagues (Winterton, Delamare-Le Deist \& Stringfellow, 2005; Delamare-Le Deist \& Winterton, 2005), who write principally with a HRD audience in mind; Mulder (2007), who focuses on the VET field; and Hyland (1993, 1997) and Weinert (2001), who examine competence-based approaches from a more general educational and philosophical perspective. In CG, Reid (2007) has made an important attempt to clarify meaning and relevance in the context of the EAS project referred to in the introductory section. However, it also needs to be said that with tacit understandings of the term giving way to demands for more precise definition, "the practical has become shrouded in theoretical confusion and the apparently simple has become profoundly complicated" (Norris, 1991, cited in Delamare-Le Deist \& Winterton, 2005, p. 29).

Usage of the term in a technical manner (e.g. in specialised literature) and with reference to a range of domains (e.g. in the area of VET, in assessing, training and recruiting managers, in teacher education, in compulsory education, in career guidance and so on) suggests that despite the conceptual ambiguity, there are nevertheless specific sets of related meanings associated with the word competence, and with such cognate terms as core (or key or basic) competences, competence management, competence balance (or bilan des compétences), competence assessment, competence mapping, competence-based training, competence frameworks, and so on. The fact that the term is used to capture or shape practises in the real world invites critical engagement rather than cynical dismissal, if only because there are a number of fundamental issues at stake-including the definition of the nature and goals of learning and of assessment.

The case of the EU is instructive in this regard. While there is no single, authoritative definition of the word competence, there seems to be an increasing consensus that the term should not be used in a narrowly technicist manner to refer to just skills, precisely because of the implications this has for education and training. An example of this consensus is the composite, comprehensive definition used in a Commission Staff Working Document relating to the European Qualifications Framework (European Commission, 2005). This draws on a range 
of EU documents as well as on relevant research literature from France, the UK, Germany and the USA, and suggests that

Competence includes: (i) cognitive competence involving the use of theory and concepts, as well as informal tacit knowledge gained experientially; (ii) functional competence (skills or know-how), those things that a person should be able to do when they are functioning in a given area of work, learning or social activity; (iii) personal competence involving knowing how to conduct oneself in a specific situation; and (iv) ethical competence involving the possession of certain personal and professional values. (European Commission, 2005)

\section{Aspects and levels of competence}

Such a definition in fact echoes critical (and classical) humanist philosophy in acknowledging the complex nature of knowledge, and is therefore, useful in helping us try to pin down a stable meaning or set of meanings to the term. Knowledge is therefore, not just a matter of savoir and savoir faire but also requires savoir être (e.g. values, attitudes, motivation, resources). Knowing, doing and being are integrated in an inter-disciplinary and holistic manner, so that a competent person is one who, by definition, is capable of combining — whether explicitly or tacitly- the different aspects of the knowledge and skills she/he possesses in response to challenges and situations as they arise in particular contexts. The various degrees of competence relate to the ability of an individual to deal with complexity, unpredictability and change, so that the higher the level of competence, the more evidence there is of self-directedness and critical reflection (or meta-competence) on the part of the practitioner, in whichever field or domain. These levels or ladders of competence (see Dreyfus, 1992; Coles \& Oates, 2005) are important because they acknowledge stages of professional development from novice to expert, with highly proficient practitioners being distinguished by their ability to bring together several dimensions of knowledge in response to work-related situations, such as having access to a body of systematically organised specialist knowledge, ability to analyse problems qualitatively, and displaying strong self-monitoring skills.

Towards a holistic view of competence

The attractiveness of this multi-dimensional definition arises from its ability to integrate the key approaches to competences that have emerged over time in different parts of the world. Winterton and his colleagues (2005) propose a typology by means of which one can make sense of the difference in the use of competencebased education and training in different contexts. The authors note that some of the important inflexions of meaning in the use of the term competence arise from the national contexts in which the notion has been operationalised, reflecting variations in the underlying philosophy. They contrast three dominant approaches which developed more or less independently, namely behaviouristic in the USA, functionalistic in the UK, and holistic and multi-dimensional in France, Germany 
(and, by extension, Austria). The authors (a) show that over time, there has been a convergence between these different approaches, and (b) suggest that there is an emergent holistic competence typology that can be identified. They argue that each of the approaches has its strengths:

The traditional American approach has demonstrated the importance of individual characteristics and the use of behavioural competence as a means of developing superior performance. The mainstream UK approach has shown the value of occupationally defined standards of functional competence and their applicability to the workplace. The approach adopted in France and Germany demonstrates the potential of a multi-dimensional and more analytical concept of competence. (Delamare-Le Deist \& Winterton, 2005, p. 40)

Current holistic/integrative approaches to competence-based models, therefore, seem to have successfully absorbed insights from the behaviouristic and functionalist approaches, and additionally integrated some of the most promising practises in education and training, such as project-based and team learning, autonomous and problem-based learning, formative assessment strategies emphasising what learners can rather than cannot do, and so on (see Perrenoud, 1997; de Ketele, 2006). For this reason, holistic approaches have been able to address many of the criticisms levelled at earlier models, and to propose adequate schemas on the basis of which useful practises supporting the provision of quality services can be generated.

\section{Key issues and challenges for competence approaches in CG}

The CG field has much to learn from these developments. The holistic approach to competence and competence frameworks provides the field with the main conceptual categories or building blocks, as well as with an underlying philosophy regarding the nature of knowledge, and the relationship between component parts. There remain, however, several issues that need to be carefully considered by the CG field as it tries to adopt and adapt competence approaches in its quest for improved quality. One way of articulating and engaging with these issues is by considering some of the tensions implicit in the use of the term competence. After analysing over 40 definitions of competence, Mulder (2007) concludes that differences arise along a number of dimensions, including the following: job focus versus role focus; context free versus context specificity; knowledge versus capability; behaviour versus ability; specificity versus generality; learnability versus unchangeability; performance versus development orientation; core versus peripheral capabilities; and the person versus the system as carrier of competences. These dimensions are important because they have implications for the way competences are recognised, measured, assessed, developed, certified, and rewarded. This contribution tries to tease out the implications that these inter-related dimensions have for the CG field, and for attempts to develop competence frameworks in ways that acknowledge and do justice to the complexities - as well as epistemological and ideological contestations-that such an endeavour entails. The goal is to alert the 
guidance community to these tensions, rather than to comprehensively cover all the issues that can potentially arise-and less still to resolve them.

Job versus role focus

Any attempt to identify the competences required by practitioners engaged in any complex endeavour needs to decide whether its focus will be on the job or on the roles that have to be fulfilled. This issue is particularly relevant to the CG field, where role identity is often unclear and difficult to specify or to operationalise in job descriptions (Reid, 2007, p. 7). In many ways, the professional role covers more competences (and in more depth) than the job does or allows (Sultana \& Watts, 2000a, 2000b). In some cases, job titles have paraprofessional incumbents who are playing CG roles, even though these are not formally recognised as such. A focus on the job as formally defined rather than on the roles that are practically fulfilled can potentially lead to overlooking the tacit knowledge and skills of practitioners, especially if competence is treated as context-free. The way people respond to complex work situations rarely accords with formal job descriptions. Additionally, formally defined work tasks may superficially appear very similar, but often prove to be quite diverse in terms of the required occupational competence (Rauner, 2007).

This raises issues regarding who defines required competences, and how. There are important choices to be made here: it is one thing for competence frameworks to be formulated by leaders or experts (academic or managerial) in a top-down manner in relation to established knowledge (e.g. theoretical models; research evidence; charters of user rights; service requirements), and quite another if such frameworks are generated on the basis of observation of recognised best practise amongst practitioners in a bottom-up manner. Both approaches have their strengths and weaknesses. A key consideration here is which strategy is best suited to ensure sensitivity towards changing roles in a rapidly changing environment. If frameworks are built around the competences excellent practitioners have demonstrated in the past, they may fail to identify evolving competence requirements unless they are updated regularly.

\section{Context free versus context specificity}

Another issue that is relevant to the CG field as it attempts to identify competences and articulate a competence framework is whether competences are fixed and stable capacities that a practitioner has, irrespective of the context she/he is operating in, or whether they become manifest (or obscured) when they are scaffolded (or impeded) by specific environmental elements (e.g. cultural or linguistic context). This has important implications for the transfer of learning: any competence-based approach to training needs to consider whether competences learned, practised and assessed in a particular context will travel well to other contexts. Context has specific relevance to the $\mathrm{CG}$ field, given that practitioners bring with them proxy qualifications that in principle signal competences in other fields than guidance (see Sultana, 2004; Sultana \& Watts, 2000a, 2000b). In addition, CG practitioners put their 
competences to use in a wide range of settings and through different modes of delivery. Some-such as guidance staff in the French public employment serviceare engaged in role rotation. Others work in contexts where services are delivered in a tiered manner. Both examples highlight the challenge for any competence framework to capture and do justice to context. The question arises as to whether one should develop a maximal competence framework applicable to all practitioners (and is the case with the IAEVG Competency Framework referred to at the start of the article) or whether one should use such a generic approach as a resource in developing more context- (and role-) specific competence frameworks (where minimal standards for each separate role are articulated).

A key challenge here would be sensitivity to the socio-cultural assumptions that underlie what one defines as competence. The issue here is whether what is being defined as competence is a universal generic attribute, or whether it is dependent on contingencies of time and space, thus revealing and highlighting the fact that what counts as a competence in any given context is socially constructed (Lum, 1999). This has serious implications for ethnic minorities and marginalised groups, who might value different competences (e.g. social and emotional competence), or value the same competences in different ways, but may be excluded from practicing CG because formal frameworks have established requirements in absolute terms and congealed around specific worldviews. It also has implications for the definition of guidance competences in diverse cultural settings (see Sultana \& Watts, 2007, 2008), and in settings where scale has important implications on how one defines core and specialist competences (Sultana, 2006).

\section{Knowledge versus capability}

This dimension raises questions about the optimal balance between the different elements of competence (in terms of knowing that, knowing how, and being) and the weighting that should be given to each when it comes to assessment and licensure, for instance. In respect to this, issues arise as to whether important elements of competence are being missed when practitioners are accredited on the basis of their experiential learning and performance against competence frameworks. The Accreditation of Prior (Experiential) Learning, as well as some approaches to bilan des compétences, tend to privilege knowing how over knowing that, and tacit knowledge over codified knowledge, giving little importance to knowledge of theoretical frameworks. Competence approaches that acknowledge the importance of the latter would be careful to define levels of competence and, as with the European Qualification Framework, reserve the higher levels to those practitioners who have the wider meta-knowledge to reflectively, critically and creatively make sense of - and informed judgements about-the situations and challenges they confront at work.

\section{Behaviour versus ability}

Definitions of competence which stress behavioural routines as convincing evidence of ability clash with other approaches which question the extent to which going 
through the motions in the pre-determined manner (e.g. as specified in service manuals) qualifies the behaviour as competence (and if so, at what level). Reference has already been made earlier to competence approaches that are inspired by behaviouristic principles. Critics of the latter typically note that a focus on behaviour (both skills and sub-skills) can lead to a mechanistic, fragmentary, do-itby-numbers approach that leads to deskilling and demotivation, not to mention bad practise. Furthermore, it can be the basis for bureaucratic, micro-management of individuals where the professional ethos of responsibility and autonomy is jeopardised. This is counterproductive in the sense that achievement motivationi.e. the need to experience competence through excellent performance-can be jeopardised. Sultana and Watts (2000a) have noted the extent to which this kind of behaviouristic approach is being introduced in some of the quality assurance protocols in the CG field, especially in Public Employment Services.

Competence frameworks that focus on behaviour therefore, raise issues about the extent to which they support or erode discretion and creativity in responding to role demands on the job. Some approaches recognise the presence of competence only when individuals mobilise, apply and integrate acquired knowledge in complex, diverse and unpredictable situations (Perrenoud, 1997). Some consider this integrative ability as central, i.e. they value the ability to master a macrocompetence that involves the holistic assimilation of several related, subsidiary skills mastered previously, and linked to a family or category of situations. Here we do not have a mere juxtaposition of a set or sequence of behaviours, but rather a situation where the whole is greater than the sum of its parts (de Ketele, 2006). Here too is where meta-cognition comes into its own, concerned as it is with the ability to cope with uncertainty, as well as with learning and reflection.

An important issue here, however, is the extent to which the notion of competence is more than a descriptive term. Earlier a case was made for an integrative and holistic view of competence, one which emphasises the fact that the internal structure of a competence comprises knowledge, skills, attitudes, and an additional element that brings all the parts together in special ways in response to specific situations. However, as Westera (2001) correctly points out,

It is not clear how this something extra associated with competence can be influenced and how its role as an explanatory variable can be tested. As a consequence, we have to see competence as no more than a descriptive term that could easily be replaced with other terms like, e.g. 'conditions for successful performance', 'divine expertise', 'magical touch', and the like. (p. 81)

This critique evidently has important implications for competence based approaches to professional development.

A radical challenge to behaviour-focused competence frameworks raises issues as to whether the behaviour to be focused on should only be that exhibited by the CG practitioner, or also by the client. In other words, the question here is whether the focus should be on the practitioner's actions or on the consequences of his/her actions, in terms of desirable activities on the part of the user (e.g. the client is now considering a broader range of options outside of the gender-stereotyped ones she/ 
he started off with). This certainly helps to alert the CG field to consider whether competence frameworks for practitioners should be complemented by competence frameworks for users.

\section{Specificity versus generality}

A further issue that arises out of competing definitions and approaches to the notion of competence is whether CG competence frameworks (and by implication, CG training programmes) should focus on so-called generic competences (i.e. contentand context-free abilities and aptitudes) or on specific ones (i.e. clusters of prerequisites - including content-specific knowledge, skills and routines- that must be available for a practitioner to perform well in a particular area). Frameworks that identify competences at a generic level would, for instance, highlight the need for CG practitioners to have listening skills. Those that are more attentive to specificity of context would, for instance, attempt to flesh out the kinds of competences needed by CG staff employed to offer guidance through a distance mode (telephone, internet, video conferencing). Choices have to be made here, with generic skills training having the advantage of facilitating flexibility and mobility in the deployment of human resources, at the risk, however, of missing out on specific elements that may or may not be learned on the job.

Such choices may be motivated by interests which are not necessarily consonant with those of service users. From the point of view of practitioners, for instance, generic skills training can enhance employability prospects, while from the point of view of the employer, having CG staff with specific skills profiles may increase efficiency and decrease turnover. Recent advances in research on situated cognition suggest that generic skills have little utility and may not be transferable across different knowledge domains. It is specific knowledge, embedded in experience, that is necessary to use personal resources and competences to overcome specific practical problems (Brown, Collins \& Duguid, 1989). This approach challenges traditional distinctions between knowledge that and knowledge how, which underpin some of the more behaviourist competence frameworks, and raises questions about the value of competence frameworks that focus exclusively on generic, de-contextualised skills. Frameworks that try to embed competences in specific contexts, however, run into other sorts of problems that have already been referred to, i.e. generating lists that are too complex, technical, unwieldy and bureaucratic.

\section{Learnability versus unchangeability}

An important though often unarticulated issue that underpins all definitions of competence is the extent to which competences are structural attributes of the individual, which become manifest through performance. In other words, the key question here is whether there are specific competences that some individuals will never be able to master, or whether all competences required by $\mathrm{CG}$ practitioners can be taught or learnt. Related issues here are whether the same competence remains stable across time, or whether it evolves (i.e. whether there is progression or 
regression in terms of mastery). Competence frameworks need to make the learning theory underpinning them transparent, for much of the orientation towards training and performance assessment depends on this. An institution or sector that emphasises learnability of competences will most likely give a great deal of importance to training and self-development programmes, and is more likely to accept the fact that while it has the right to expect certain skills, values and attitudes from its employees, it also has the responsibility to provide them with training opportunities and powerful learning environments.

On the other hand, an institution or sector that works with the notion of unchangeability is more likely to acknowledge the fact that at least some of the behaviours identified in competence frameworks are personality traits which an individual may be unable (or even unwilling) to change. This raises questions as to whether professions have the right (or obligation) to identify the personality structure that makes a person fit to become a licensed practitioner. In doing so, however, professions may run the risk of admitting members with broadly similar profiles, thus losing out on the advantages that diversity brings with it. The danger here is also that of having desired profiles linked to only one system of normative or cultural-embedded values, rather than flexibly integrating competing systems.

\section{Performance versus development orientation}

As was noted from the outset, competence frameworks are generally developed for two reasons. The first is to identify competences in ways that enable the assessment of performance in relation to set standards. The intention here is mainly to manage staff, or to establish levels of competence attained after initial, induction or inservice training. A second motive for developing frameworks is to provide a guide for self-evaluation, self-development as well as training programme development. While the two reasons are not necessarily mutually exclusive, the difference in orientation and motivation may have an impact on what elements in a competence framework are given more (or less) importance, and how the framework is received by practitioners. The dynamics underpinning the development of the framework are also likely to be different, with the latter being more likely than the former to involve practitioners (and possibly service users) in the development of the framework.

\section{Core versus peripheral capabilities}

Some frameworks distinguish between core and peripheral competences. It is not always very clear, however, whether competences are core because they are required by all practitioners in all sectors and at all levels, or whether they are core in the sense that they are basic or minimal requirements, i.e. without them, a practitioner cannot advance to other levels of competence. Yet another interpretation of core competences is in relation to transversal competences, i.e. those that cut across and inform all or most other competences (e.g. gender sensitivity; understanding of multi-cultural issues; awareness of the specific challenges faced by persons with disabilities). 
Such differentiation and interrogation is neither a merely academic exercise: rather, it has important implications, including political and ideological ones. The following case will illustrate the point I am trying to make here. If core competences are those competences formally required from all practitioners for the purpose of licensure, who decides what is fundamental to a profession, what is peripheral, and what is irrelevant? It is easy to imagine a situation where developers of competence frameworks are reluctant to include the ability to mobilise political resources in favour of clients as a core advocacy competence all practitioners should have. It is also easy to imagine a situation where, dependent on the ideological perspectives of framework developers and competence evaluators, the warrant to practise is given to-or withheld from-a CG service provider which demonstrates mastery in several so-called 'core' competences, but which has no interest in advocacy work. What is core and what is peripheral are clearly political and not just technical questions.

The person versus the system as carrier of competences

Behaviourist approaches tend to see the individual as the unit of analysis, and as the carrier of competences. Constructivist approaches tend to see the individual as nested in a community of practitioners (Lave \& Wenger, 1991), where competence is a function both of individual and shared capacity (Boreham, 2004). In this approach, learning as a path from inability to ability is to be seen as a process of integration into the community of practise of those who already demonstrate expertise (Rauner, 2007). We are here therefore, in the realm of a social network of competences that facilitate the best use of available institutional resources for achieving the goals of the institution (Weinert, 2001).

Whether frameworks adopt an individualist or community of practise approach to competences has important implications for a number of related issues. It has implications, for instance, for attempts to measure competence, what these measurements mean, and whether generally applicable frameworks and performance indicators that are used to assess competence across different institutional settings are meaningful. There are also implications as to whether competence gaps can be plugged simply by buying in specific competences. It raises questions as to whether a competence framework should focus solely on individual attributes, or whether it should integrate and reflect the fact that competences can be also attributed to-and distributed within-social groups and institutions. It also has implications for the modality of training that is likely to be most effective, for the linkages between pre-service, induction and in-service training, and for conceptualising agencies that deliver CG services as learning organisations.

\section{Conclusion}

Clearly, then, the use of a competence approach to improve career guidance services is not unproblematic. Any attempt to shape the field of CG by identifying what qualities and traits $\mathrm{CG}$ practitioners should aspire to develop, and what training 
programmes can do in order to promote the development of such traits, should be mindful of the complex and contested issues that surround the endeavour. Ways must be found to address the critiques that have been made of the different versions of competence-based approaches over time, particularly their tendency (a) to be reductionist and fragmentary in relation to tasks that are complex and integrative of many dimensions of the self; (b) to define good practise solely in relation to institutional norms rather than in consultation with practitioners or service users; and (c) to forget that there are aspects of human behaviour which are more likely to be caught rather than taught, and that therefore, excellence is sometimes the result not of targeted training as much as of socialisation into (and by) a community of established practitioners. Acknowledgement of these and related critiques suggests that not only must the identification of competences and the articulation of a competence framework be open-ended in spirit and scope, but also that competencebased training is just one from a broad range of approaches, which may potentially provide equally if not more valid routes into the profession.

\section{References}

Barnett, R. (1994). The limits of competence: Knowledge, higher education and society. Buckingham, UK: Open University Press.

Bates, I. (1995). The competence movement and the National Vocational Qualification framework: The widening parameters of research. British Journal of Education and Work, 8(2), 5-13.

Boreham, N. (2004). A theory of collective competence: Challenging the neo-liberal individualisation of performance at work. British Journal of Educational Studies, 52, 5-17.

Brown, J. S., Collins, A., \& Duguid, P. (1989). Situated cognition and the culture of learning. Educational Researcher, 18(1), 32-42.

Brown, M., Patrick, F., Tate, D., \& Wright, S. (Eds.). (1994). Competency-based training: A collection of readings. Geelong, Victoria: Deakin University.

Canning, R. (2007). Reconceptualising core skills. Journal of Education and Work, 20(1), 17-26.

Career Industry Council of Australia [CICA] (2006). Retrieved 21 August 2008 from www.cica.org.au.

Chartered Institute of Personnel and Development. (2007). Competency and competency frameworks. CIPD Fact sheet. London: Chartered Institute of Personnel and Development.

Clarke, L., \& Winch, C. (2006). A European skills framework?-but what are skills? Anglo-Saxon versus German concepts. Journal of Education and Work, 19(3), 255-269.

Coburn, C. E., \& Stein, M. K. (2006). Communities of practise theory and the role of teacher professional community in policy implementation. In M. I. Honig (Ed.), New directions in education policy implementation: Confronting complexity (pp. 25-46). Albany: SUNY Press.

Coles, M., \& Oates, T. (2005). European reference levels for education and training promoting credit transfer and mutual trust (Cedefop Panorama Series, 109). Luxembourg: Office for Official Publications of the European Communities.

Delamare-Le Deist, F., \& Winterton, J. (2005). What is competence? Human Resource Development International, 8(1), 27-46.

de Ketele, J.-M. (2006). La notion émergente de compétence dans la construction des apprentissages [The emergent notion of competence in the construction of learning]. In G. Figari \& L. M. Lopez (Eds.), Recherche sur l'évaluation en éducation [Research on evaluation in education] (pp. 17-24). Paris: L'Harmattan.

Dreyfus, H. (1992). What computers still can't do: A critique of artificial reason. Cambridge, MA: MIT Press.

European Commission (2005). Towards a European Qualifications Framework for lifelong learning. Commission Staff working document, SEC (2005) 957. Brussels: Author. Retrieved 21 August 2008 from http://ec.europa.eu/education/policies/2010/doc/consultation_eqf_en.pdf. 
Evangelista, L. (2007). Up patriots to arms! Why and how to structure a European framework for accrediting career guidance practitioners. Retrieved 21 August 2008 from http://www.orientamento. it/english/patriots.htm.

Hyland, T. (1993). Competence, knowledge and education. Journal of Philosophy of Education, 21(1), 57-68.

Hyland, T. (1997). Reconsidering competence. Journal of Philosophy of Education, 31(3), 491-503.

International Association for Educational and Vocational Guidance (2004). International competencies for educational and vocational guidance practitioners. Retrieved August 21, 2008 from http://www.iaevg.org/iaevg/nav.cfm?lang=2\&menu=1\&submenu=5.

Lave, J., \& Wenger, E. (1991). Situated learning: Legitimate peripheral participation. Cambridge: Cambridge University Press.

Lum, G. (1999). 'Where's the competence in competence-based education and training? Journal of Philosophy of Education, 33(3), 403-418.

Mulder, M. (2007). Competence-the essence and use of the concept in ICVT. European Journal of Vocational Training, 40(1), 5-21.

National Steering Committee for Career Development Standards and Guidelines (2001). Canadian Standards and Guidelines for Career Development Practitioners. Ottawa, ON: Author. Retrieved August 21, 2008 from www.career-dev-guidelines.org.

Norris, N. (1991). The trouble with competence. Cambridge Journal of Education, 21(3), 331-341.

Perrenoud, P. (1997). Construire des compétences dès l'école. pratiques et enjeux pédagogiques [Starting with the school in the construction of competences: pedagogical practises and priorities]. Paris: ESF Éditeurs.

Rauner, F. (2007). Practical knowledge and occupational competence. European Journal of Vocational Training, 40(1), 52-66.

Reid, H. L. (2007). Study on the accreditation schemes of OECD countries. Study prepared for the Leonardo da Vinci project "European Accreditation Scheme for Career Guidance Practitioners". Retrieved 21 August, 2008 from http://www.corep.it/eas/home.htm.

Repetto, E. (2008). International competencies for educational and vocational guidance practitioners: An IAEVG trans-national study [Monograph]. International Journal for Educational and Vocational Guidance, 8(3).

Roelofs, E., \& Sanders, P. (2007). Towards a framework for assessing teacher competence. European Journal of Vocational Training, 40(1), 123-139.

Schön, D. (1987). Educating the reflective practitioner: Towards a new design for teaching and learning in the professions. San Francisco, CA: Jossey-Bass.

Sultana, R. G. (2004). Guidance policies in the learning society: Trends, challenges and responses across Europe. Thessaloniki: CEDEFOP.

Sultana, R. G. (2006). Challenges for career guidance in small states. Malta: EMCER.

Sultana, R. G., \& Watts, A. G. (2000a). Career guidance in Europe's public employment services: Trends and challenges. Brussels: DG Employment, Social Affairs and Equal Opportunities.

Sultana, R. G., \& Watts, A. G. (2000b). Career guidance in public employment services across Europe. International Journal for Educational and Vocational Guidance, 6(1), 29-46.

Sultana, R. G., \& Watts, A. G. (2007). Career guidance in the Mediterranean. Turin: ETF.

Sultana, R. G., \& Watts, A. G. (2008). Career guidance in the middle east and north Africa. International Journal for Educational and Vocational Guidance, 8(1), 19-34.

Weinert, F. E. (2001). Concept of competence: A conceptual clarification. In D. S. Rychen \& L. H. Salganik (Eds.), Defining and selecting key competencies (pp. 46-65). Seattle: Hogrefe \& Huber.

Westera, W. (2001). Competences in education: A confusion of tongues. Journal of Curriculum Studies, $33(1), 75-88$.

Winterton, J., Delamare-Le Deist, F., \& Stringfellow, E. (2005). Typology of knowledge, skills and competences: Clarification of the concept and prototype (Panorama Series, No. 1397). Luxembourg: Office for Official Publications of the European Communities.

Woodruffe, C. (1991). Competent by any other name. Personnel Management, 23(9), 30-33. 